\title{
Climate capitalism and the global corporate elite network
}

\author{
December 2015 \\ Environmental Sociology 1(4): 268-279 \\ (http://dx.doi.org/10.1080/23251042.2015.1111490)
}

Jean Philippe Sapinski

Department of Sociology

University of Oregon, USA

Email: sapinski@uvic.ca

Web: uoregon.academia.edu/JPSapinski

\section{Abstract}

This paper explores the political involvement of transnational corporations and their directors in elaborating the project of 'climate capitalism' advanced to address climate change. Climate capitalism seeks to redirect investments from fossil energy to renewable energy generation, so as to foster an ecological modernization of production and reduce greenhouse gas (GHG) emissions. I use social network analysis to assess the potential for climate capitalism, as a project of a section of the corporate elite, to replace the current 'carboniferous capitalist' regime. Corporate-funded climate and environmental policy groups (CEPGs) constitute major venues for the corporate elite to assemble and plan their response to the climate crisis. By mapping out the network of board-level interlocks between CEPGs and the largest transnational corporations, I first find that certain CEPGs are centrally located among the global intercorporate network, and thus well positioned to promote climate capitalism among the corporate elite. Second, I delineate a climate capitalist inner circle that includes the individual members of the corporate community who arguably are able to exert the greatest power to shape climate capitalism. However, many of them, close to the oil and nuclear sectors, may support a long-term transition away from fossil fuels, incompatible with avoiding dangerous climatic warming.

\section{Keywords}

Climate capitalism, Climate politics, Transnational corporations, Interlocking directorates, Inner circle, Social network analysis. 


\section{Climate capitalism and the global corporate elite network}

\section{Introduction}

This paper explores the political involvement of transnational corporations and their directors in elaborating the project of climate capitalism advanced to address climate change. The expression 'climate capitalism' designates the neoliberal attempt to mitigate climate change through market measures that turn aspects of nature into new means of accumulation while minimizing end-of-pipe, direct state regulation of greenhouse gas (GHG) emissions (Newell and Paterson 2010; see also Bumpus and Liverman 2008; Lohmann 2010). At its face value, climate capitalism promotes the use of carbon markets, carbon taxes, and other financial mechanisms as means to redirect investment flows away from the polluting fossil fuel sector and toward more climatically benign renewable electricity generation and energy efficiency initiatives. These new, reorganized investment patterns would foster an ecological modernization of production processes and lead to reduced GHG emissions (Böhm and Dabhi 2009; Newell and Paterson 2010). For its proponents, climate capitalism would thus reconcile capital accumulation and climate change mitigation by making the latter profitable for capitalist firms themselves, hence drawing on their economic interest to draw them into the project of reducing GHG emissions (see e.g. Lovins and Cohen 2011). This project is contrasted with the business-as-usual scenario of fossil fuel driven 'carboniferous capitalism' (Newell and Paterson 2010) ${ }^{1}$, but also with transformative proposals seeking more radical changes in the capitalist political economy, such as those of a 'green new deal', of economic degrowth toward a steady-state economy, or of ecosocialism (Candeias 2013).

Climate capitalism has been harshly critiqued, not the least because carbon markets - still the main climate capitalist policy instrument (Sterk et al. 2015) - appear unlikely to actually lead to a meaningful reduction in GHG emissions (Böhm and Dabhi 2009; Lohmann 2006, 2011; Vlachou 2014). On the contrary, many argue that carbon markets have only been effective in two respects: 1) in facilitating capital accumulation through dispossession and privatization of the commons in the global South, and encouraging speculation and rent-seeking among owning elites (Lohmann 2008:361; see also Foster and Clark 2009; Isla 2015; Fairhead et al. 2012); 2) in delaying action to mitigate global warming, a partly unintended consequence yet also an outcome welcomed by all those corporations dependent on fossil fuels (Derber 2010; Lohmann 2006; Lohmann and Böhm 2012). The latter is especially true since the economic crisis that erupted in 2008 has actually brought a much increased dependence on fossil fuel-based accumulation as a means of generating short-term profits (Bitter 2011; Lohmann and Böhm

The expression is from Lewis Mumford (2010 [1934]). 
2012). For their part, carbon taxes have had little effect in the few jurisdictions where they have been implemented (Brännlund et al. 2014; Lin and Li 2011; Smith 2011)². Thus, it is argued that in contrast to its discourse of ecological modernization, climate capitalism has had - at least up to now - the same effects as the carboniferous capitalist regime it purports to supplant, that is, to delay GHG emissions reduction while facilitating corporate profit.

Corporate-supported think tanks and policy-planning groups play a crucial role in constructing projects, such as climate capitalism, that seek to maintain capitalist relations by transforming them (van der Pijl 1998). The work performed by these organizations consists in 1) producing knowledge that informs and legitimates certain types of economic governance while delegitimizing others, and 2) mobilizing this knowledge by linking elite networks across sectoral and national boundaries, thus facilitating convergence of ideas and consensus-making (Burris 2008; Carroll and Carson 2003; Carroll and Sapinski 2010). That is, 'they provide an organizational basis for the emergence, articulation, and diffusion of ideas within the groups, factions and classes in which they are embedded' (Sapinski 2015).

In the field of climate politics, corporate-funded climate and environmental policy groups (CEPGs), such as the International Emissions Trading Association and the World Business Council for Sustainable Development, play such a role of knowledge production and mobilization (KPM). CEPGs conduct intensive lobbying with governments and UN agencies to promote climate capitalism. They also send representatives to the yearly UN Conferences of Parties (COPs), where they hold side-events as part of their KPM activities, to which corporate managers and policy-makers are invited (Tansey 2013). More importantly for this paper, by virtue of their organizational structure, they function as places where the corporate elite and other elites can meet, plan strategy, forge consensus on key issues, and create a sense of community around the climate capitalist project (see Carroll and Sapinski 2010; Domhoff 2014). In this way, they constitute major venues where responses to the climate crisis are debated, and provide a crucial capacity to bridge lines of fraction among corporate elites from different regions and economic sectors (Sapinski 2015).

This paper assesses the role of CEPGs in constructing the hegemony of climate capitalism among the global corporate elite. It uses social network analysis (SNA) to map out the constellations of corporate power in which CEPGs are embedded. The analysis will address the question whether climate capitalism, as a hegemonic project (Jessop 1990), stands a chance of overtaking the currently existing regime of carboniferous capitalism and become hegemonic among the global corporate elite. By doing so, it will contribute to found empirically debates

The British Columbia carbon tax might be an exception (Elgie and McClay 2013; although see Bumpus 2015). 
among analysts of climate politics (see Bond 2013; Hahnel 2012; Lohmann 2011, 2012; Paterson and Newell 2012) and potentially inform political action.

Whereas previous research I conducted outlined the existence of a climate capitalist policyplanning network (Sapinski 2015), this paper assesses the reach of the CEPGs at the core of that network into the very top layers of the global corporate community. This will shed light on the position the climate capitalist project occupies within the broader field of global corporate power. On the basis of this assessment, I will discuss: (1) the possibility of an eventual corporateled transition to a climate capitalist production regime, and (2) what consensus on climate capitalism may actually be achieved given the different political-economic interests represented on CEPG boards. In what follows, I will first provide details on the SNA methodology. The second section will then discuss briefly the discourse and action repertoire of the CEPGs that make up the core of this study. Next, the main analyses explore where CEPGs stand within the global field of corporate power, here operationalized as the 500 largest corporations in the world and the network of board-level interlocks that connects them together (Carroll 2010). For this, (1) considering the network at the interorganizational level where corporations and CEPGs link together, I will look at the position CEPGs occupy among the network of G500 interlocking directorships; (2) looking at the network at the interindividual level, I will delineate an 'inner circle' of climate capitalism composed of a small number of key individuals who bind the field together (Sapinski 2015). A brief overview of inner circle members' corporate affiliations will provide an indication as to the eventual policy content of climate capitalism and thus whether it has any potential to avoid catastrophic climate change.

\section{Methodology}

The study starts from a judgement sample of ten CEPGs that were selected on the basis of 1) their transnational reach and mandate, and 2) their core function of climate capitalist KPM. Table 1 provides basic information about the policy groups making up the sample.

[Table 1. Climate and environmental policy groups]

The analysis looks at the embeddedness of these ten CEPGs within the network of interlocking directorships among the 500 largest transnational corporations (in terms of revenue, subsequently designated as the G500). Two corporations are said to 'interlock' when a member of the board of corporation A also sits on the board of corporation B. Considered independently, such links between corporations serve many purposes: evidence of firm reputation, information channels, and at times influence or control by one firm over another (Mizruchi 1996). Considered as a system, they form an extensive network that links most large corporations together in a dense web of relationships (Carroll 2010; Stokman et al. 1985), evidence that 
corporations are embedded in and construct a network of social relations that reaches beyond the corporations themselves (de Graaff 2012). In its interorganizational aspect, this network provides corporate managers with insider information and thus plays a crucial role in coordinating corporate economic activity and business strategy (Carroll and Sapinski 2011; Domhoff 2014; Mintz and Schwartz 1985). As an interindividual network, it constitutes an extensive infrastructure on which can develop greater cohesion among the corporate elite, fundamental for organized political action (Burris 2005; Carroll and Sapinski 2011; Domhoff 2014; Murray 2013; Useem 1984). Additionally, interlocks between corporations and other organizations - in this case CEPGs - can be meaningfully analyzed as extended structures of corporate power (e.g. Burris 2008; Carroll and Beaton 2000; Carroll and Carson 2003; Carroll and Sapinski 2010). These linkages allow large firms and their owners and managers to project the power they derive from controlling the main centres of accumulation directly onto the political and cultural arenas (Carroll 2004). The SNA methodology employed in this paper allows me to map out some of these channels through which corporations exert structural power. In this way, it approaches power as a function of the whole system of relations between firms and of their relative positions within this structure (de Graaff 2011). Such a view of structural power underlies the analysis presented below.

I established the list of G500 corporations for 2010 on the basis of the Fortune Global 500 list published in June 2011 that ranks the largest corporations by revenue ${ }^{3}$. From this list, I constructed a stratified sample that includes the largest 400 industrial firms ranked by revenue and the largest 100 financial firms ranked by assets, so as to account for the underrepresentation of one or the other sector in the Fortune list. Constructing such a stratified sample is considered best practice in studies based on a list of the largest national or global corporations (e.g. Carroll 2010; Stokman et al. 1985) ${ }^{4}$. For each corporation, I then collected the list of all directors using the LexisNexis Corporate Affiliations database; Bureau van Dijk’s Mint Global database was used to complete the information when necessary. For firms using the dual board system, both boards were merged and are considered as a single entity in the analyses, as per previous studies ${ }^{5}$.

Available online: http://fortune.com/global500/2011, consulted in October and November 2011.

This sampling strategy originally served to account for the fact that banks and other financial corporations generally declare lower revenues despite the fact that they control vast assets. Such a stratified sample thus avoids underrepresenting financial capital. In this case though, the situation was the opposite, as the 2010 G500 list included 391 industrial firms and 109 financial firms. To ensure comparability with previous studies, I nonetheless constructed a sample of 400 industrial and 100 financial firms.

5 For the purpose of the following analyses, directors of subsidiary firms who also are directors of one or more CEPG have been included as if they were board members of the parent corporation. This is to account for the fact that CEPGs' boards are at times staffed with lower-level managers and directors of subsidiaries of major corporations, who do not sit on the parent company's board but still represent it on CEPG boards. These linkages, despite the fact that they are not board interlocks in the classic sense, are meaningful and need to be considered in this study. They represent channels of communication between firms and CEPGs, and are indicative of an interest in influencing the climate capitalist project. 


\section{Action repertoire and discourse of climate capitalist policy groups}

Beyond their common organizing and consensus-making roles discussed above, each CEPG specializes in particular aspects of climate capitalist KPM. Thus, all CEPGs lobby governments and intergovernmental organizations (IGOs) to a certain extent, yet the Business Council for Sustainable Energy (BCSE) and the International Emissions Trading Association (IETA) direct the greater part of their resources to such activities. Similarly, though all groups function as think tanks, the Global Climate Forum's (GCF) main activities consist in publishing reports and sponsoring conferences where different views about climate capitalist tools and strategies can be debated. For their part, the Climate Group, the World Business Council for Sustainable Development (WBCSD) and the UN Global Compact, by virtue of their high level networks, are able to work closely with governments and UN agencies to develop policies or economic arrangements supportive of climate capitalism. In this regard, the Climate Group works actively with subnational governments to deploy on-the-ground projects, such as installing energyefficient street lighting, that serve to create markets for so-called 'green' commodities. For its part, the Global Environmental Management Initiative (GEMI) focuses on its member corporations for whom it develops benchmarking tools against which to measure the extent to which they incorporate climate capitalist principles in their activities. Finally, the Copenhagen Climate Council (CCC), the UN Global Compact, and the WBCSD uniquely function as high level forums where the CEOs of the world's largest corporations collaborate together and interact with high-ranking politicians and civil servants to forge the main aspects of the climate capitalist project. Thus, CEPGs each have their own unique ways to conduct climate capitalist KPM, and in so doing carve out specific niche for themselves in the complex field of global climate politics.

Yet, despite their variegated action repertoires, all CEPGs present a similar discourse. The common narrative presented in their public material reflects very closely neoliberal ideals of reduced direct state intervention and voluntary corporate measures to address environmental issues ${ }^{6}$. This narrative goes as follows: 'business', once governments provide it with the appropriate 'playing field' - i.e. minimal global standardized regulations, substantial financial incentives, and, very importantly, the bureaucratic infrastructure required to administer carbon markets and other climate capitalist instruments - will use its special power of innovation to solve climate and sustainability issues by developing and applying techno-fixes that will provide new sources of profit and relaunch global economic growth. In terms of the actors involved in this tale, business represents the main, and often only, force of change; governments at best play a minor support role to corporate action, and at worst are a hindrance; NGOs, when present, can

This discourse is found in the public material disseminated by each CEPG, available on their respective websites; for a more detailed description of CEPGs' activities, see Sapinski (2015). 
be junior partners whose role is not specifically defined; human beings are non-existent in themselves, and appear only under the form of a population to be employed or managed; similarly, ecosystems are sources of wealth in the form of natural capital and thus objects to be managed as well. This discourse is easily recognized as that of neoliberal environmentalism (see Bernstein 2002; Büscher and Fletcher 2015; Sullivan 2013) and rests heavily on a 'Promethean' view of technology as all powerful (see Dryzek 2013). In line with the neoliberal discourse (Castree 2010; Collard et al. 2015), it diverts attention from the substantial state intervention and investments required by climate capitalism by emphasizing the superior agency of 'business' and a reduced role of the state. All CEPGs subscribe to this discourse, with the exception of the Club of Rome. The Club of Rome instead supports neo-Keynesian measures relying on direct largescale state intervention to stabilize the climate and address other environmental issues (see Custers 2010), although its discourse nonetheless stays within the parameters of elite management of the 'earth system'.

\section{Climate capitalism and the interlocks network of Global 500 corporations}

Figure 1 is a graphic representation of the main component of the G500 interlocks network with embedded CEPGs; it includes 325 corporations and nine out of the ten original CEPGs. The corporations linking to CEPGs are indicated in black on the figure. The figure suggests that a sizeable proportion of these firms interested in climate capitalism are closely embedded within the dense core of the network. The other way around, most CEPGs have links to multiple G500 corporations. The proportion of G500 firms on each CEPG board varies: the BCSE has no links at all to G500 firms (and hence does not appear on Figure 1), while the Global Climate Forum, the Club of Rome, the GEMI, the Global Compact and the WBCSD have more than half their links to G500 firms. Thus, the largest corporations do play a role in the governance of most CEPGs, a crucial one in many cases. Conversely, many CEPGs link closely with corporations allegedly among the most powerful in the world.

[Figure 1. CEPGs in the G500 interlocks network (main component)]

Table 2 compares the structural position of each CEPG within the interlocks network so as to assess how closely connected they are to core G500 corporations. Centrality analysis determines which nodes are the most important in a network. It can be measured in many ways, depending on what is considered to make a node structurally important in a given network (Borgatti et al. 2013:164; Freeman 1979). Table 2 lists the 35 most central CEPGs and firms in the network according to four different measures. The first one, degree centrality, simply represents the number of ties connecting a node to other nodes. The second one, closeness centrality, is calculated as the sum, for each node, of the number of steps - i.e. the number of intermediaries - 
that connect it to every other node in the graph; it thus measures how easily on average one node can reach any other (Freeman 1979; Sabidussi 1966). The third measure, betweenness centrality, measures the extent to which each node mediates relations between other nodes. It calculates, for each node, the sum of the proportion of shortest distance paths between all pairs of nodes that pass through it (Freeman 1977, 1979). The values reported in Table 2 for these three measures are normalized according to network size, and thus vary between zero and one. Finally, beta centrality is a more complex metric that is based on the assumption that influential nodes are those linked to other central nodes. To account for this, it adjusts the centrality of each node proportionally to the centrality of directly adjacent nodes, themselves dependent on the centrality of nodes adjacent to them, and so on, recursively (Bonacich 1987). A parameter, beta, is used to weight the impact nodes located farther away will have on each node's centrality score. At a beta value of zero, beta centrality gives all the weight to local connections and the result is hence equivalent to degree centrality; at its maximum value ${ }^{7}$, it weights a node's centrality according to the centrality of nodes located at any distance, and thus gives greater weight to the global structure of the network ${ }^{8}$. For the case at hand, I am interested in the potential for the diffusion of climate capitalist ideas and practices among the most important corporations of the global political-economy. I hence seek to identify the nodes with the greatest potential to influence the debates around whether global capitalism should reorient along the lines of climate capitalism. Those would not necessarily be the ones with only the most direct contacts (degree), nor those with the best ability to reach across the network (closeness), nor those located in brokerage positions (betweenness), although each of these measures does capture one specific aspect of network influence. What I am rather seeking is a combination of local and global network influence, which is precisely what the beta centrality measure captures (Bonacich 1987:1174). So as to strike that balance between local and global influence, and to account for the smaller influence of a node on nodes located farther away, I assigned a beta parameter equal to half the maximum possible value.

\section{[Table 2. Measures of centrality for G500 firms and CEPGs]}

The WBCSD registers as the most central CEPG according to all metrics (Table 2). This is because of its organizational structure, as a forum of CEOs or chairs of the largest corporations. Among its 69 directors, 42 head G500 corporations, thus providing the WBCSD with a unique reach and influence at the top, reflected in its extremely high centrality scores relative to other

7 The reciprocal of the largest eigenvalue of the network's adjacency matrix represents the limit at which the equation does not converge anymore. The maximum allowable value for Beta would thus be the closest possible to this value (Borgatti et al. 2013:171), approximated in the Ucinet software package by 0.995 times the reciprocal of the largest eigenvalue (Borgatti et al. 2002).

8 In which case it is equivalent to eigenvector centrality, as described by Bonacich (1972).; see Bonacich (1987), Borgatti et al. (2013:171). 
nodes. Of the other CEPGs, the Global Compact, the IETA, and the Club of Rome consistently rank among the 35 most central nodes or close. Additionally, the CCC makes it to the $20^{\text {th }}$ rank in closeness, and the Global Climate Forum appears at the $30^{\text {th }}$ rank for betweenness. However, the other CEPGs rank much lower in terms of the different dimensions of centrality. Thus, it appears that several CEPGs beyond the Global Compact and the WBCSD, already known to be among the most influential global policy groups, occupy locations of potential influence among the G500, either in terms of the number of corporations they connect with, of their reach, of their capacity to broker between otherwise unconnected firms, or of how much they interlock with well-connected corporations. These CEPGs are well positioned to play a crucial role in drawing the largest corporations into an eventual climate capitalist coalition.

Looking at the issue from another angle, many corporations that manifest an interest in climate capitalism through their presence on policy boards also appear among the most powerful G500 firms. In all, the 69 G500 corporations represented on CEPG boards represent 13.8\% of the total. However, among the 31 most powerful G500 corporations as measured by beta centrality, 16 have a presence on at least one policy board (indicated by stars in the table), making up $51.6 \%$ of this small group of corporations. Of course, the centrality of these firms is enhanced by the fact that they link to the most central CEPGs. To assess whether CEPGs do indeed link with the most powerful G500 corporations independently of their acting as cohesive hubs, I computed centrality scores for all nodes excluding CEPGs and tested if the difference in means between those firms that link to CEPGs and those that do not was significant for all centrality measures. The t-tests results are reported in Table 3. These show that the G500 firms that are represented on CEPG boards are significantly more central than those that are not, according to all metrics considered. Thus, independently of the inclusion of CEPGs in the network, firms interested in climate capitalism appear to occupy more central positions and wield above-average power within the network of interlocking directorates that ties together the select circle of G500 corporations.

[Table 3. Difference in mean centrality for G500 firms involved in CEPG governance or not, various measures]

\section{The inner circle of climate capitalism}

Several authors have underscored the importance of analyzing both the intercorporate and interindividual aspects of interlocks networks (Breiger 1974; Carroll 1984; Palmer 1987; Scott 1985). Here, I will approach the question of the position of the climate capitalist project within global capitalism from the angle of corporate directors, considered as members of the capitalist class participating in a system of class power (see Scott 1985). 
Following Carroll and Sapinski's (2010) study of the global corporate-policy elite, I define the climate capitalist corporate-policy elite as those corporate directors who also sit on one or more CEPG boards, i.e. the individuals who create the actual network between policy groups and corporations (illustrated by the shaded area in Table 4). Within that broad climate capitalist elite, it is possible to delineate a more restricted group constituted by the most active members of the corporate elite and associated organic intellectuals. Borrowing from Useem (1984), I will identify this group as the climate capitalist inner circle. I include in this inner circle individuals who sit on two or more corporate boards and one or more CEPG board, thus capturing corporate interlockers who are active in the field of climate politics. To this group, I add directors of more than one CEPG who are not corporate directors. This latter category includes other important organic intellectuals who, despite not being included in the global corporate elite as such, nonetheless play an important role in developing its class interests and ideas as well as in creating greater connectivity among its members. The climate capitalist inner circle thus defined includes 21 corporate-policy interlockers and six policy-only interlockers, 27 individuals in total. Its members are listed in Table 5, and their interconnections are represented graphically in Figure 2.

\section{[Table 4. CEPG and corporate board membership]}

[Figure 2. The inner circle of climate capitalism]

We see from Table 5 that several important corporate directors are part of the climate capitalist elite and are thus active in constructing and building support for the project. Taking a broad view of the whole climate capitalist network, we find that out of the 405 CEPG directors, 79 are also G500 directors (19.3\%). Looking specifically at the climate capitalist inner circle, 19 of its 27 members (70.4\%) are G500 directors; moreover, 11 of these directors carry interlocks between G500 corporations, and thus are part of the most connected segment of the global corporate elite (see Useem 1984). Thus, the climate capitalist inner circle includes several top capitalists, who may indeed be well positioned to influence the direction of global capitalism and an eventual transition to a new regime of capitalist accumulation. These eleven people nevertheless represent a very small fraction of the 544 G500 interlockers (2.0\%). Still, inner circle members do reach extensively beyond the climate capitalist inner circle, and the 11 G500 interlockers link directly with 244 other G500 interlockers (44.9\%) with whom they share one or more board memberships, as illustrated in Figure 3. Nearly half of the most connected section of the global capitalist elite is within direct reach of climate capitalist inner circle members.

[Table 5. The inner circle of climate capitalism]

[Figure 3. Climate capitalist inner circle members among G500 interlockers] 


\section{Discussion}

The stated goal of the climate capitalist project is to divert financial flows from the oil and coal sectors and GHG-emitting electricity production, and to redirect them to support the ecological modernization of production processes. In political-economic terms, this would involve implementing a new regime of capital accumulation, based on the partial internalization of certain environmental externalities, which following Newell and Paterson (2010) I have termed 'climate capitalism'. CEPGs play a crucial role to conceptualize this new regime and to mobilize the corporate elite in support of it. The analysis presented above (1) shows that climate capitalism is a project of a section of the global corporate elite that reaches out to a considerable segment of the corporate community; (2) sheds doubt on the claims of analyses presenting climate capitalism and carboniferous capitalism as elite projects with antagonistic goals.

The first thing the analysis demonstrates is that CEPGs are closely connected to the global corporate elite, at the highest level of organizational decision-making, the board of directors. As such, they function as vehicles of corporate elite power and hegemony, helping project its interests in the political and cultural realms (see Carroll 2004). Despite the fact that the intercorporate network creates a strong basis for cohesion and coordinated political action (Burris 2005; Murray 2013), it is nonetheless divided by major lines of fracture over strategy and tactics (Robinson and Harris 2000). This paper has focused on a cleavage that has become prominent during the last two decades, the division over the strategy to adopt in face of climate change. I charted the position of CEPGs within the interlocks network that connects the world's largest corporations together. Through this analysis, I explored where these organizations, whose work is to forge the climate capitalist project, stand in relation to the global corporate elite as a whole.

Starting from this line of fracture, the main question this paper addresses is whether the project of climate capitalism has the potential to become hegemonic among the global corporate elite. Analyzing the interlocks network along its interorganizational dimension shows that: (1) many CEPGs are well interlocked with the largest corporations, and (2) overall, CEPGs tend to interlock with the most central firms. These findings suggest that CEPGs are indeed well positioned to mobilize the largest and the most interlocked corporations around the project of climate capitalism. Considering the interlocks network as a channel for investment information (Mizruchi 1996), participation in CEPGs may increase firms' awareness of 'low carbon' profit opportunities. This would contribute to make firms more knowledgeable of the advantages of climate capitalism and thus deepen their commitment to the project. More importantly though, looking at the system of interlocks as a more diffuse vector of elite cohesion (Domhoff 2014) suggests that CEPGs may contribute to pulling together the corporate community around the 
project of climate capitalism. They provide meeting points for corporate elites to discuss strategic responses to the climate crisis and forge consensual positions on the issue. They also provide services that are useful to corporations so that they can adopt internal policies in line with climate capitalism, which allows the integration of climate capitalism as a set of practices. Finally, the other way around, they serve to project corporate power onto the political and cultural fields (Carroll 2004), thereby fostering structural transformations that could help further climate capitalist hegemony.

Analyzing the network at the level of interindividual connections provides a complementary perspective. The analysis identified the most central individuals on whom depend most of the interlocks between corporations and CEPGs, and who together form a climate capitalist 'inner circle'. The inner circle includes several top capitalists, who may indeed be well positioned to influence the direction of global capitalism and an eventual transition to a new regime of accumulation. The extensive reach of these individuals among the global corporate elite again supports the argument of a potential for a broad climate capitalist coalition to form. However, analysis of the inner circle also fosters some questions about climate capitalism and its hegemonic potential. First, the small number of people at the core of the network outlines the fragility of this network, which could easily disorganize if one or more of these inner circle members would somehow withdraw from it ${ }^{9}$. Thus, the capacity of CEPGs and the climate capitalist elite to foster broad support for climate capitalism might be more limited than the interorganizational-level analysis suggests.

Second, shifting focus to inner circle members suggests that the interests these individuals are tied to are more compatible with a 'weak' version of climate capitalism involving a slow transition to sustainable energy production over the long term. Indeed, CEPGs also represent an outlet for the corporate elites participating in their governance to shape the project of climate capitalism according to their own beliefs and interests. Looking at the 11 G500 interlockers' affiliations listed in Table 5, we see that five of them are linked to major oil and nuclear energy corporations. The two most central individuals of the network, Anne Lauvergeon and Charles Holliday, are directors of oil majors Total and Shell, respectively. Lauvergeon is also CEO of nuclear power plant constructor Areva and a director of natural gas major GDF-Suez. Her compatriot Henri Proglio is CEO of Électricité de France (EDF) whose energy production depends in majority on nuclear power plants. Isidro Fainé, chair of Barcelona-based credit union La Caixa, represents his firm's investments on the board of Spanish oil major Repsol. Finally, Jorma Ollila is chairman of Shell. The fact that these key people are so closely tied to nonrenewable energy interests suggests that they may very well support a weak project of climate

See Heemskerk (2013). 
capitalism founded on a slow transition to ecologically modernized production, which would allow for the short-term valorization of the large sums of capital invested in fossil fuel and nuclear energy production. This observation is consistent with existing literature (e.g. Derber 2010; Jones and Levy 2007; Lohmann 2011; Sapinski 2015) and indicates that despite their emergence within distinct sections of the corporate elite, climate capitalism and carboniferous capitalism may share similar long term goals.

\section{Conclusion}

In conclusion, SNA allowed the analysis to move beyond considering organizations, firms, or CEPGs, in isolation and instead acknowledge the global corporate field as an ensemble of social relations. It thus moves beyond looking at whether individual firms adopt climate capitalist policies or not (e.g. Levy and Kolk 2002), or the degree to which each CEPG supports climate capitalism (e.g. Vormedal 2008). As a whole, the global corporate community is both cohesive and divided. SNA captures both aspects so as to reconceptualize the field as a site of struggle over corporate strategy in the face of the foreseen costs of runaway climate change.

Analysts of climate politics have been debating over whether the climate capitalist project might eventually get the support of a majority of the corporate community. The analysis presented here sheds light on this debate by showing that climate capitalist organizations occupy crucial positions within the G500 interlocks network. Nonetheless, CEPGs' reach rests on only a few individuals, meaning that the success of climate capitalism is far from assured. Furthermore, individual-level analysis brings out crucial questions about what type of climate capitalism might draw consensus among the corporate elite. Would a strong climate capitalism entailing a rapid regime shift toward the ecological modernization of production, including the reorganization of capital flows and thus of corporate profits, draw broad adhesion? Or would corporate support instead coalesce around a weak version which, while appearing to address the issue, would in practice only serve to maintain the current economic and financial structure, and thus amount to a continued denial of global warming? The evidence presented here suggests the latter, though

further research would be required to delineate the actual content of the climate capitalist project and its meaning for individual members of the climate capitalist inner circle. 


\section{References}

Bernstein, Steven. 2002. The Compromise of Liberal Environmentalism. New York: Columbia University Press.

Bitter, Martin. 2011. "Contradictions of the Commodity Carbon - On the Material and Symbolic Production of a Market.” Pp. 71-93 in After Cancún, edited by Elmar Altvater and Achim Brunnengräber. Wiesbaden: VS Verlag für Sozialwissenschaften.

Böhm, Steffen and Siddhartha Dabhi, eds. 2009. "Upsetting the Offset: An Introduction.” Pp. 924 in Upsetting the offset: the political economy of carbon markets. London: MayFlyBooks.

Bonacich, Phillip. 1972. "Factoring and Weighting Approaches to Status Scores and Clique Identification." The Journal of Mathematical Sociology 2(1):113-20.

Bonacich, Phillip. 1987. "Power and Centrality: A Family of Measures." American Journal of Sociology 92(5):1170-82.

Bond, Patrick. 2013. "Climate Crisis, Carbon Market Failure, and Market Booster Failure: A Reply to Robin Hahnel's 'Desperately Seeking Left Unity on International Climate Policy.” Capitalism Nature Socialism 24(1):54-61.

Borgatti, Stephen P., Martin G. Everett, and Jeffrey C. Johnson. 2013. Analysing Social Networks. London: SAGE Publications.

Borgatti, Steve P., Martin G. Everett, and Linton C. Freeman. 2002. Ucinet for Windows: Software for Social Network Analysis. Harvard (MA): Analytic Technologies.

Brännlund, Runar, Tommy Lundgren, and Per-Olov Marklund. 2014. "Carbon Intensity in Production and the Effects of Climate policy-Evidence from Swedish Industry." Energy Policy 67:844-57.

Breiger, Ronald L. 1974. “The Duality of Persons and Groups.” Social Forces 53(2):181-90.

Bumpus, Adam G. 2015. "Firm Responses to a Carbon Price: Corporate Decision Making under British Columbia's Carbon Tax.” Climate Policy 15(4):475-93.

Bumpus, Adam G. and Diana M. Liverman. 2008. "Accumulation by Decarbonization and the Governance of Carbon Offsets.” Economic Geography 84(2):127-55.

Burris, Val. 2005. "Interlocking Directorates and Political Cohesion among Corporate Elites." American Journal of Sociology 111(1):249-83.

Burris, Val. 2008. “The Interlock Structure of the Policy-Planning Network and the Right Turn in 
U.S. State Policy.” Research in Political Sociology 17:3-42.

Büscher, Bram and Robert Fletcher. 2015. "Accumulation by Conservation." New Political Economy 20(2):273-98.

Candeias, Mario. 2013. Green Transformation: Competing Strategic Projects. Berlin: Rosa Luxemburg Foundation.

Carroll, William K. 1984. "The Individual, Class, and Corporate Power in Canada." Canadian Journal of Sociology 9(3):245-68.

Carroll, William K. 2004. Corporate Power in a Globalizing World: A Study in Elite Social Organization. Don Mills (ON): Oxford University Press.

Carroll, William K. 2010. The Making of a Transnational Capitalist Class: Corporate Power in the 21st Century. London and New York: Zed Books.

Carroll, William K. and James Beaton. 2000. "Globalization, Neo-Liberalism and the Changing Face of Corporate Hegemony in Higher Education.” Studies in Political Economy 62:7198.

Carroll, William K. and Colin Carson. 2003. "Forging a New Hegemony? The Role of Transnational Policy Groups in the Network and Discourse of Global Corporate Governance." Journal of World-Systems Research 9(1):67-102.

Carroll, William K. and Jean Philippe Sapinski. 2010. "The Global Corporate Elite and the Transnational Policy-Planning Network, 1996-2006: A Structural Analysis.” International Sociology 25(4):501-38.

Carroll, William K. and Jean Philippe Sapinski. 2011. "Corporate Elites and Intercorporate Networks.” Pp. 180-95 in The SAGE Handbook of Social Network Analysis, edited by Peter J. Carrington and John Scott. London: SAGE Publications.

Castree, Noel. 2010. "Neoliberalism and the Biophysical Environment: A Synthesis and Evaluation of the Research." Environment and Society: Advances in Research 1(1):5-45.

Collard, Rosemary-Claire, Jessica Dempsey, and James K. Rowe. 2015. "Re-Regulating Socioecologies under Neoliberalism." in The handbook of neoliberalism, edited by Kean Birch, Julie MacLeavy, and Simon Springer. London: Routledge.

Custers, Peter. 2010. "The Tasks of Keynesianism Today: Green New Deals as Transition towards a Zero Growth Economy?” New Political Science 32(2):173-91.

Derber, Charles. 2010. Greed to Green: Solving Climate Change and Remaking the Economy. Boulder (CO) and London: Paradigm Publishers. 
Domhoff, G. William. 2014. Who Rules America? The Triumph of the Corporate Rich. 7th ed. New York: McGraw-Hill.

Dryzek, John S. 2013. The Politics of the Earth: Environmental Discourses. Oxford: Oxford University Press.

Elgie, Stewart and Jessica McClay. 2013. "BC's Carbon Tax Shift Is Working Well after Four Years (attention Ottawa)." Canadian Public Policy 39(2S):S1-10.

Fairhead, James, Melissa Leach, and Ian Scoones. 2012. "Green Grabbing: A New Appropriation of Nature?” The Journal of Peasant Studies 39(2):237-61.

Foster, John Bellamy and Brett Clark. 2009. "The Paradox of Wealth: Capitalism and Ecological Destruction.” Monthly Review 61(6):1-14.

Freeman, Linton C. 1977. "A Set of Measures of Centrality Based on Betweenness." Sociometry 40(1):35-41.

Freeman, Linton C. 1979. "Centrality in Social Networks: Conceptual Clarification.” Social Networks 1:215-39.

de Graaff, Naná. 2011. "A Global Energy Network? The Expansion and Integration of Non-Triad National Oil Companies.” Global Networks 11(2):262-83.

de Graaff, Naná. 2012. “Oil Elite Networks in a Transforming Global Oil Market.” International Journal of Comparative Sociology 53(4):275-97.

Hahnel, Robin. 2012. "Desperately Seeking Left Unity on International Climate Policy." Capitalism Nature Socialism 23(4):83-99.

Heemskerk, Eelke M. 2013. "The Rise of the European Corporate Elite: Evidence from the Network of Interlocking Directorates in 2005 and 2010.” Economy and Society 42(1):74101.

Isla, Ana. 2015. The "Greening” of Costa Rica: Women, Peasants, Indigenous People, and the Remaking of Nature. Toronto: University of Toronto Press.

Jessop, Bob. 1990. State Theory: Putting the Capitalist State in Its Place. University Park (PA): Pennsylvania State University Press.

Jones, Charles A. and David L. Levy. 2007. "North American Business Strategies towards Climate Change.” European Management Journal 25(6):428-40.

Levy, David L. and Ans Kolk. 2002. "Strategic Responses to Global Climate Change: Conflicting Pressures on Multinationals in the Oil Industry.” Business and Politics 4(3):275-300. 
Lin, Boqiang and Xuehui Li. 2011. "The Effect of Carbon Tax on per Capita CO2 Emissions." Energy Policy 39(9):5137-46.

Lohmann, Larry. 2006. Carbon Trading: A Critical Conversation on Climate Change, Privatisation and Power. Uppsala (Sweden): The Dag Hammarskjöld Centre.

Lohmann, Larry. 2008. "Carbon Trading, Climate Justice and the Production of Ignorance: Ten Examples.” Development 51(3):359-65.

Lohmann, Larry. 2010. "Neoliberalism and the Calculable World: The Rise of Carbon Trading." Pp. 77-93 in The rise and fall of neoliberalism: The collapse of an economic order?, edited by Kean Birch and Vlad Mykhnenko. London: Zed Books.

Lohmann, Larry. 2011. "Capital and Climate Change.” Development and Change 42(2):649-68.

Lohmann, Larry. 2012. “A Rejoinder to Matthew Paterson and Peter Newell.” Development and Change 43(5):1177-84.

Lohmann, Larry and Steffen Böhm. 2012. "Critiquing Carbon Markets: A Conversation." Ephemera: Theory \& Politics in Organization 21(1):81-96.

Lovins, L. Hunter and Boyd Cohen. 2011. Climate Capitalism: Capitalism in the Age of Climate Change. New York: Hill and Wang.

Mintz, Beth and Michael Schwartz. 1985. The Power Structure of American Business. Chicago: University of Chicago Press.

Mizruchi, Mark S. 1996. "What Do Interlocks Do? An Analysis, Critique, and Assessement of Research on Interlocking Directorates.” Annual Review of Sociology 22:271-98.

Mumford, Lewis. 2010. Technics and Civilization. Chicago: University of Chicago Press.

Murray, Joshua. 2013. "Evidence of a Transnational Capitalist Class-for-Itself: The Determinants of PAC Activity among Foreign Firms in the Global Fortune 500, 2000-2006.” Global Networks 14(2): 230-250.

Newell, Peter and Matthew Paterson. 2010. Climate Capitalism: Global Warming and the Transformation of the Global Economy. Cambridge: Cambridge University Press.

Palmer, Donald. 1987. "The Dual Nature of Corporate Interlocks.” Pp. 60-74 in The Structure of Power in America: The Corporate Elite as a Ruling Class, edited by Michael Schwartz. New York: Holmes \& Meier.

Paterson, Matthew and Peter Newell. 2012. "Of Heroes, Villains and Climate Capitalism: A Response to Larry Lohmann.” Development and Change 43(5):1171-75. 
van der Pijl, Kees. 1998. Transnational Classes and International Relations. London: Routledge.

Robinson, William I. and Jerry Harris. 2000. "Towards a Global Ruling Class? Globalisation and the Transnational Capitalist Class.” Science \& Society 64(1):11-54.

Sabidussi, Gert. 1966. “The Centrality Index of a Graph.” Psychometrika 31(4):581-603.

Sapinski, Jean Philippe. 2015. "Constructing Climate Capitalism: Corporate Power and the Global Climate Policy-planning Network.” Global Networks Forthcoming.

Scott, John. 1985. "Theoretical Framework and Research Design.” Pp. 1-19 in Networks of Corporate Power: A Comparative Analysis of Ten Countries, edited by Frans N Stokman, Rolf Ziegler, and John Scott. Cambridge: Polity Press.

Smith, Richard. 2011. "Green Capitalism: The God That Failed.” Real-World Economics Review 2011(56):112-44.

Sterk, Wolfgang, Hans Bolscher, Jeroen van der Laan, Jelmer Hoogzaad, and Jos Sijm. 2015. "Developing a Sectoral New Market Mechanism: Insights from Theoretical Analysis and Country Showcases." Climate Policy 15(4):417-37.

Stokman, Frans N., Rolf Ziegler, and John Scott, eds. 1985. Networks of Corporate Power: A Comparative Analysis of Ten Countries. Cambridge: Polity Press.

Sullivan, Sian. 2013. "Banking Nature? The Spectacular Financialisation of Environmental Conservation.” Antipode 45(1):198-217.

Tansey, Rachel. 2013. The COP19 Guide to Corporate Lobbying: Climate Crooks and the Polish Government's Partners in Crime. Amsterdam: Corporate Europe Observatory and Transnational Institute.

Useem, Michael. 1984. The Inner Circle: Large Corporations and the Rise of Business Political Activity in the U.S. and U.K. New York: Oxford University Press.

Vlachou, Andriana. 2014. "The European Union's Emissions Trading System." Cambridge Journal of Economics 38(1):127-52.

Vormedal, Irja. 2008. "The Influence of Business and Industry NGOs in the Negotiation of the Kyoto Mechanisms: The Case of Carbon Capture and Storage in the CDM.” Global Environmental Politics 8(4):36-65. 
Tables 
Table 1. Climate and environmental policy groups

\begin{tabular}{|c|c|c|c|}
\hline Name $^{a}$ & Year est. & Headquarters & Main activities \\
\hline Club of Rome & 1972 & Winterthur (Switzerland) & Global elite forum, think tank \\
\hline Global Environmental Management Initiative (GEMI) & 1990 & Washington, DC (USA) & Industry support \\
\hline Business Council for Sustainable Energy (BCSE) & 1992 & Washington, DC (USA) & Lobby group \\
\hline European Business Council for a Sustainable Energy Future (e5) & 1996 & Karben (Germany) & Think tank, lobby group \\
\hline World Business Council for Sustainable Development (WBCSD) & 1996 & Geneva (Switzerland) & Global elite forum, policy planning, think tank, lobby group \\
\hline International Emissions Trading Association (IETA) & 1999 & Geneva (Switzerland) & Lobby group \\
\hline United Nations Global Compact & 2000 & New York (USA) & Global elite forum, policy planning, think tank, lobby group \\
\hline Global Climate Forum (GCF) & 2001 & Berlin (Germany) & Think tank \\
\hline The Climate Group & 2003 & Woking (UK) & Policy planning, think tank, eco-modernization projects \\
\hline Copenhagen Climate Council $(\mathrm{CCC})^{\mathrm{b}}$ & 2007 & Copenhagen (Denmark) & Global elite forum, lobby group \\
\hline
\end{tabular}


Table 2. Measures of centrality for G500 firms and CEPGs

\begin{tabular}{|c|c|c|c|c|c|c|c|c|}
\hline Rank & Degree $^{a, b}$ & & Closeness $^{a}$ & & Betweennes & a, b & Beta centralit & $\mathrm{a}, \mathrm{b}, \mathrm{c}$ \\
\hline 1 & WBCSD & 0.0843 & WBCSD & 0.17108 & WBCSD & 0.1266 & WBCSD & 8.157 \\
\hline 2 & Shell* & 0.0392 & Shell* & 0.16526 & Global Compact & 0.0293 & Shell* & 4.125 \\
\hline 3 & Total $^{*}$ & 0.0353 & $\mathrm{GE}^{*}$ & 0.16289 & Shell $^{*}$ & 0.0291 & Total $^{*}$ & 4.008 \\
\hline 4 & Saint-Gobain & 0.0314 & Global Compact & 0.16289 & IETA & 0.0242 & Saint-Gobain & 3.401 \\
\hline 5 & Global Compact & 0.0314 & $\mathrm{BP}^{*}$ & 0.16278 & Club of Rome & 0.0230 & Global Compact & 3.234 \\
\hline 6 & BNP Paribas & 0.0294 & Unilever* & 0.16247 & Alcoa* $^{*}$ & 0.0200 & BNP Paribas & 3.079 \\
\hline 7 & Deutsche Bank & 0.0294 & Deere $^{*}$ & 0.16227 & $\mathrm{BP}^{*}$ & 0.0200 & GDF-Suez* & 3.079 \\
\hline 8 & IBM & 0.0294 & Total $^{*}$ & 0.16221 & Alstom* & 0.0198 & Lafarge $^{*}$ & 3.017 \\
\hline 9 & Alcoa* & 0.0275 & Vodafone* & 0.16190 & $\mathrm{GE}^{*}$ & 0.0180 & Veolia* & 3.003 \\
\hline 10 & Allianz & 0.0275 & Chevron* & 0.16175 & Allianz & 0.0179 & Siemens* & 2.872 \\
\hline 11 & Astrazeneca & 0.0275 & Siemens* & 0.16160 & Total $^{*}$ & 0.0176 & Unilever* & 2.823 \\
\hline 12 & $\mathrm{GE}^{*}$ & 0.0275 & Alcoa* & 0.16155 & Siemens* & 0.0171 & $\mathrm{GE}^{*}$ & 2.729 \\
\hline 13 & Unilever* & 0.0275 & Veolia* & 0.16144 & Astrazeneca & 0.0171 & AXA & 2.702 \\
\hline 14 & Veolia* & 0.0275 & $\mathrm{ABB}^{*}$ & 0.16104 & Morgan Stanley* & 0.0166 & Vodafone $^{*}$ & 2.698 \\
\hline 15 & Alstom* & 0.0255 & Alstom* & 0.16063 & Vodafone $^{*}$ & 0.0160 & Deutsche Bank & 2.672 \\
\hline 16 & AXA & 0.0255 & Lafarge* & 0.16063 & IBM & 0.0157 & Alstom* & 2.649 \\
\hline 17 & $\mathrm{BP}^{*}$ & 0.0255 & GDF-Suez* & 0.16038 & UPS & 0.0152 & IBM & 2.613 \\
\hline 18 & Dell & 0.0255 & Bank of America* & 0.16003 & Sony* & 0.0152 & EADS & 2.529 \\
\hline 19 & EADS & 0.0255 & IETA & 0.15992 & Deere* & 0.0151 & Alcoa* $^{*}$ & 2.509 \\
\hline 20 & GDF-Suez ${ }^{*}$ & 0.0255 & cCC & 0.15933 & Ericsson & 0.0140 & $\mathrm{BP}^{*}$ & 2.495 \\
\hline 21 & Lafarge $^{*}$ & 0.0255 & Novartis & 0.15933 & CCC & 0.0135 & Deere $^{*}$ & 2.425 \\
\hline 22 & Siemens* & 0.0255 & IBM & 0.15903 & Swiss $\operatorname{Re}^{*}$ & 0.0133 & Allianz & 2.389 \\
\hline 23 & Air France-KLM & 0.0235 & Rio Tinto* & 0.15903 & Chevron* & 0.0130 & Dell & 2.387 \\
\hline 24 & Deere* & 0.0235 & Saint-Gobain & 0.15898 & Unilever* & 0.0129 & Astrazeneca & 2.328 \\
\hline 25 & E.ON & 0.0235 & Dell & 0.15893 & Veolia* & 0.0128 & Société Générale* & 2.243 \\
\hline 26 & L’Oréal & 0.0235 & Nokia* & 0.15848 & Renault & 0.0128 & Air France-KLM & 2.180 \\
\hline 27 & Metro & 0.0235 & Holcim* & 0.15843 & Toyota* & 0.0127 & L'Oréal & 2.120 \\
\hline 28 & Procter \& Gamble* & 0.0235 & Astrazeneca & 0.15839 & $\mathrm{ABB}^{*}$ & 0.0119 & Chevron* & 2.032 \\
\hline 29 & Renault & 0.0235 & Ericsson & 0.15834 & Pepsi Co. & 0.0119 & $\mathrm{EDF}^{*}$ & 2.005 \\
\hline 30 & $\mathrm{RWE}^{*}$ & 0.0235 & Cigna* $^{*}$ & 0.15824 & Global Cl. Forum & 0.0112 & Novartis & 2.003 \\
\hline 31 & Société Générale* & 0.0235 & Michelin* & 0.15809 & Dell & 0.0110 & IETA & 1.966 \\
\hline 32 & UPS & 0.0235 & Philips & 0.15804 & Pfizer & 0.0110 & Zurich Financial & 1.966 \\
\hline 33 & Vodafone $^{*}$ & 0.0235 & BNP Paribas & 0.15775 & United Tech & 0.0108 & E.ON & 1.954 \\
\hline 34 & Club of Rome & 0.0235 & $\mathrm{EDF}^{*}$ & 0.15770 & Novartis & 0.0105 & Sanofi-Aventis & 1.919 \\
\hline 35 & [8 firms ex-aequo] & 0.0216 & [EADS and Roche] & 0.15765 & Mitsui* $^{*}$ & 0.0102 & Club of Rome & 1.911 \\
\hline- & IETA & 0.0216 & Club of Rome & 0.15712 & Climate Group & 0.0018 & CCC & 1.839 \\
\hline- & $\operatorname{ccc}$ & 0.0196 & Global Cl. Forum & 0.15361 & GEMI & 0.0004 & Global Cl. Forum & 1.481 \\
\hline- & Global Cl. Forum & 0.0196 & GEMI & 0.14693 & e5 & 0.0000 & GEMI & 0.759 \\
\hline- & GEMI; CI. Group & 0.0098 & Climate Group & 0.14638 & & & Climate Group & 0.612 \\
\hline- & e5 & 0.0059 & e5 & 0.14186 & & & e5 & 0.330 \\
\hline
\end{tabular}

a CEPGs' names are in bold italics; stars indicate firms that directly interlock with at least one CEPG.

${ }^{b}$ Normalized scores.

${ }^{\mathrm{c}}$ Beta $=0.0517$. 
Table 3. Difference in mean centrality for G500 firms involved in CEPG governance or not, various measures

\begin{tabular}{lccccc}
\hline Centrality measure & $\begin{array}{c}\text { Mean, firms on } \\
\text { CEPG boards }\end{array}$ & $\begin{array}{c}\text { Mean, firms not on } \\
\text { CEPG boards }\end{array}$ & $\mathbf{t}^{\mathbf{b}}$ & $\mathbf{p}$ & Eta $^{\mathbf{2}}$ \\
\hline Beta centrality & $8.1(7.1)$ & $3.9(5.4)$ & 32.608 & 0.0001 & 0.061 \\
Degree & $4.9(3.9)$ & $2.5(3.1)$ & 32.378 & 0.0001 & 0.061 \\
Betweenness & $651.6(925.3)$ & $247.0(545.3)$ & 25.655 & 0.0001 & 0.049 \\
Closeness & $4711.0(1218.4)$ & $5394.8(1406.1)$ & 14.323 & 0.0001 & 0.028 \\
\hline N observations & 69 & 431 & 500 & 500 & 500 \\
\hline
\end{tabular}

a Standard deviation in brackets.

${ }^{\mathrm{b}}$ All tests based on 10,000 permutations. 
Table 4. CEPG and corporate board memberships

\begin{tabular}{ccccc}
\hline \multirow{2}{*}{$\begin{array}{c}\text { N corporate } \\
\text { directorships }\end{array}$} & \multicolumn{3}{c}{ N CEPG directorships } & Total \\
\cline { 2 - 4 } & $\mathbf{0}$ & $\mathbf{1}$ & $\mathbf{2}$ & \\
\hline 0 & - & 238 & 5 & 243 \\
1 & 2503 & 140 & 1 & 2644 \\
2 & 63 & 14 & 2 & 79 \\
3 & 3 & 3 & 0 & 6 \\
4 & 0 & 0 & 2 & 2 \\
\hline Total & 2569 & 395 & 10 & 2974 \\
\hline
\end{tabular}


Table 5. The inner circle of climate capitalism

\begin{tabular}{|c|c|c|c|c|c|}
\hline $\begin{array}{c}\text { Climate capitalist } \\
\text { inner circle }\end{array}$ & $\begin{array}{l}\text { CEPG } \\
\text { boards }\end{array}$ & $\begin{array}{l}\text { Corp. } \\
\text { boards }\end{array}$ & $\begin{array}{c}\text { G500 } \\
\text { boards }\end{array}$ & CEPG boards & Corporate boards \\
\hline \multicolumn{6}{|l|}{ G500 interlockers } \\
\hline Anne Lauvergeon & 2 & 4 & 3 & Global Compact, WBCSD & $\begin{array}{l}\text { Areva (CEO), GDF-Suez, } \\
\text { Vodafone, Total }\end{array}$ \\
\hline Charles O. Holliday, Jr. & 2 & 4 & 3 & Global Compact, WBCSD & $\begin{array}{l}\text { Bank of America (chair), Deere \& } \\
\text { co., } \mathrm{CH} 2 \mathrm{MHill} \text {, Shell }\end{array}$ \\
\hline Ernesto Zedillo & 1 & 3 & 3 & Club of Rome & $\begin{array}{l}\text { Alcoa, Citigroup, Procter \& } \\
\text { Gamble }\end{array}$ \\
\hline Henri Proglio & 1 & 3 & 3 & WBCSD & $\begin{array}{l}\text { EDF (CEO), Véolia Envir. (chair), } \\
\text { CNP Assurances }\end{array}$ \\
\hline Isidro Faine Casas & 1 & 3 & 2 & Club of Rome & $\begin{array}{l}\text { La Caixa (chair), Repsol, } \\
\text { Telefónica }\end{array}$ \\
\hline Fujio Cho & 1 & 2 & 2 & WBCSD & Totota (chair), Sony \\
\hline Jorma Ollila & 1 & 2 & 2 & WBCSD & Nokia (chair), Shell (chair) \\
\hline Matt Brittin & 1 & 2 & 2 & Climate Group & $\begin{array}{l}\text { Google UK (managing director), } \\
\text { J. Sainsbury }\end{array}$ \\
\hline Michel Rollier & 1 & 2 & 2 & WBCSD & Michelin (CEO), Lafarge \\
\hline Paul Polman & 1 & 2 & 2 & WBCSD & Unilever (CEO), Dow \\
\hline Paul S. Otellini & 1 & 2 & 2 & $\mathrm{CCC}$ & Intel (CEO), Google \\
\hline \multicolumn{6}{|l|}{ Other G500 directors } \\
\hline James E. Rogers & 2 & 2 & 1 & CCC, WBCSD & Duke Energy (CEO), Cigna \\
\hline Samuel A. DiPiazza & 2 & 2 & 1 & CCC, WBCSD & $\begin{array}{l}\text { PricewaterhouseCoopers (CEO), } \\
\text { DirecTV }\end{array}$ \\
\hline Kasper Rorsted & 1 & 2 & 1 & WBCSD & Henkel (CEO), Danfoss \\
\hline Lee A. McIntire & 1 & 2 & 1 & WBCSD & $\begin{array}{l}\text { CH2MHill (president and CEO), } \\
\text { BAE }\end{array}$ \\
\hline Reto Ringger & 1 & 2 & 1 & Club of Rome & $\begin{array}{l}\text { Globalance Bank (founder and } \\
\text { CEO), SwissRe }\end{array}$ \\
\hline Toshio Arima & 1 & 2 & 1 & Global Compact & $\begin{array}{l}\text { FujiXerox (president), Kirin } \\
\text { Holdings }\end{array}$ \\
\hline Ingnacio Campino & 2 & 1 & 1 & e5, Global Climate Forum & $\begin{array}{l}\text { Deutsche Telekom (rep. of the } \\
\text { management board for } \\
\text { sustainability and cl. change) }\end{array}$ \\
\hline \multicolumn{6}{|l|}{ Other corporate interlockers } \\
\hline Carsten Bjerg & 1 & 2 & 0 & $\mathrm{CCC}$ & $\begin{array}{l}\text { Grundfos (CEO), Vestas Wind } \\
\text { Systems }\end{array}$ \\
\hline David Gregson & 1 & 2 & 0 & Climate Group & $\begin{array}{l}\text { Lets Filofax (chair), Precise } \\
\text { Media (chair) }\end{array}$ \\
\hline Scott Sklar & 1 & 2 & 0 & BCSE & $\begin{array}{l}\text { Stella Group (founder and CEO), } \\
\text { SkyBuilt Power }\end{array}$ \\
\hline Subhash Chandra & 1 & 2 & 0 & $\mathrm{CCC}$ & Essel (chair), Zee Entertainment \\
\hline \multicolumn{6}{|l|}{ Policy group interlockers } \\
\hline Bjorn Stigson & 2 & 0 & 0 & WBCSD (president), CCC & - \\
\hline Crispin Tickell & 2 & 0 & 0 & CCC, Club of Rome & - \\
\hline Frederick C. Dubee & 2 & 0 & 0 & $\begin{array}{l}\text { Global Compact (senior advisor), } \\
\text { Club of Rome }\end{array}$ & - \\
\hline Georg Kell & 2 & 0 & 0 & $\begin{array}{l}\text { Global Compact (executive } \\
\text { director), CCC }\end{array}$ & - \\
\hline Sebastian Gallehr & 2 & 0 & 0 & e5 (CEO), Global Climate Forum & - \\
\hline
\end{tabular}


Figures

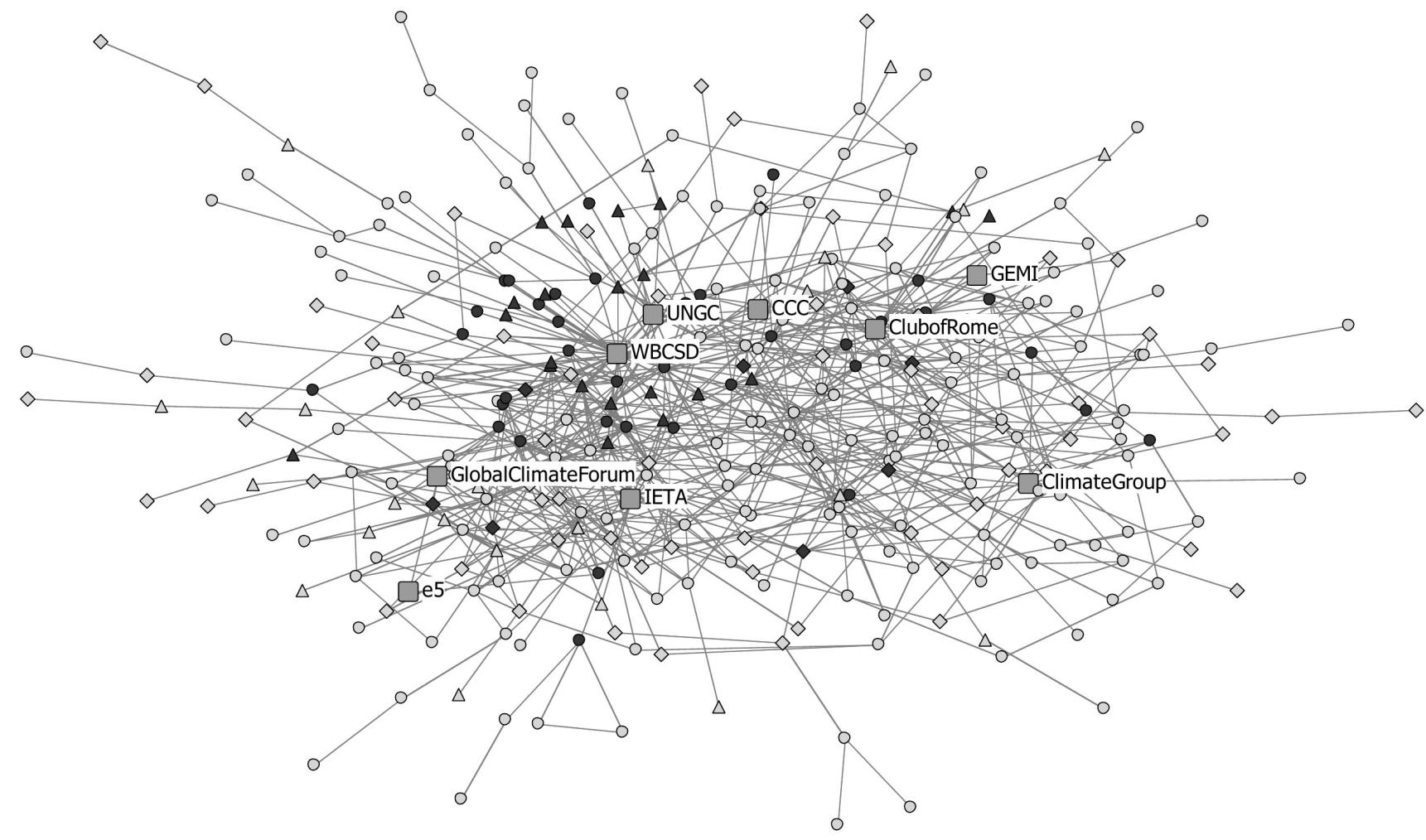

Key

Squares: CEPGs Diamonds: Financial corporations Triangles: Energy corporations Circles: Other corporations Black: Corporations linked to CEPGs Light gray: Other corporations

Figure 1. CEPGs in the G500 interlocks network (main component) 


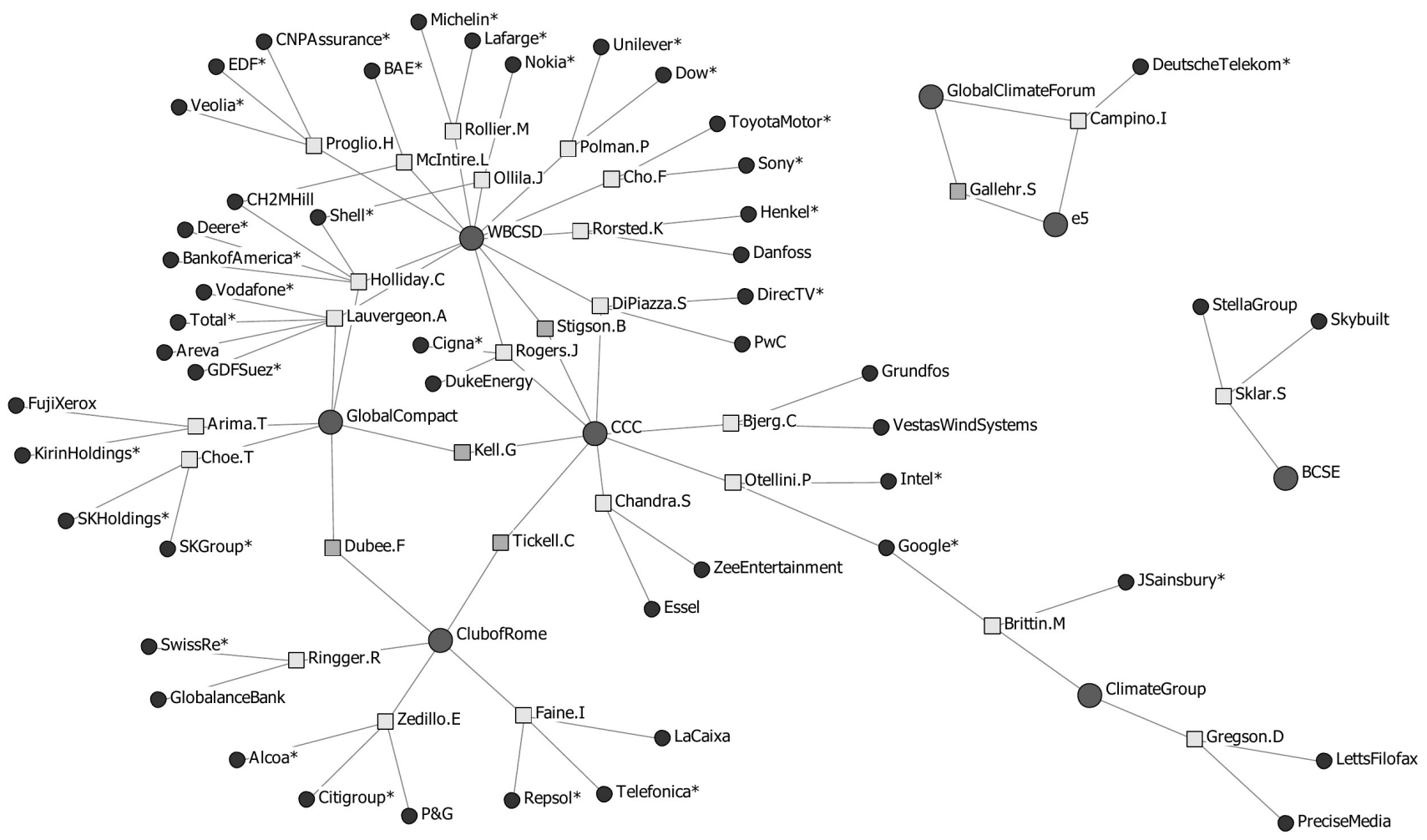

Key

Large dark gray circles: CEPGs Small black circles: Corporations Light gray squares: Corporate directors Gray squares: Policy group interlockers. Stars indicate G500 corporations.

Figure 2. The inner circle of climate capitalism 


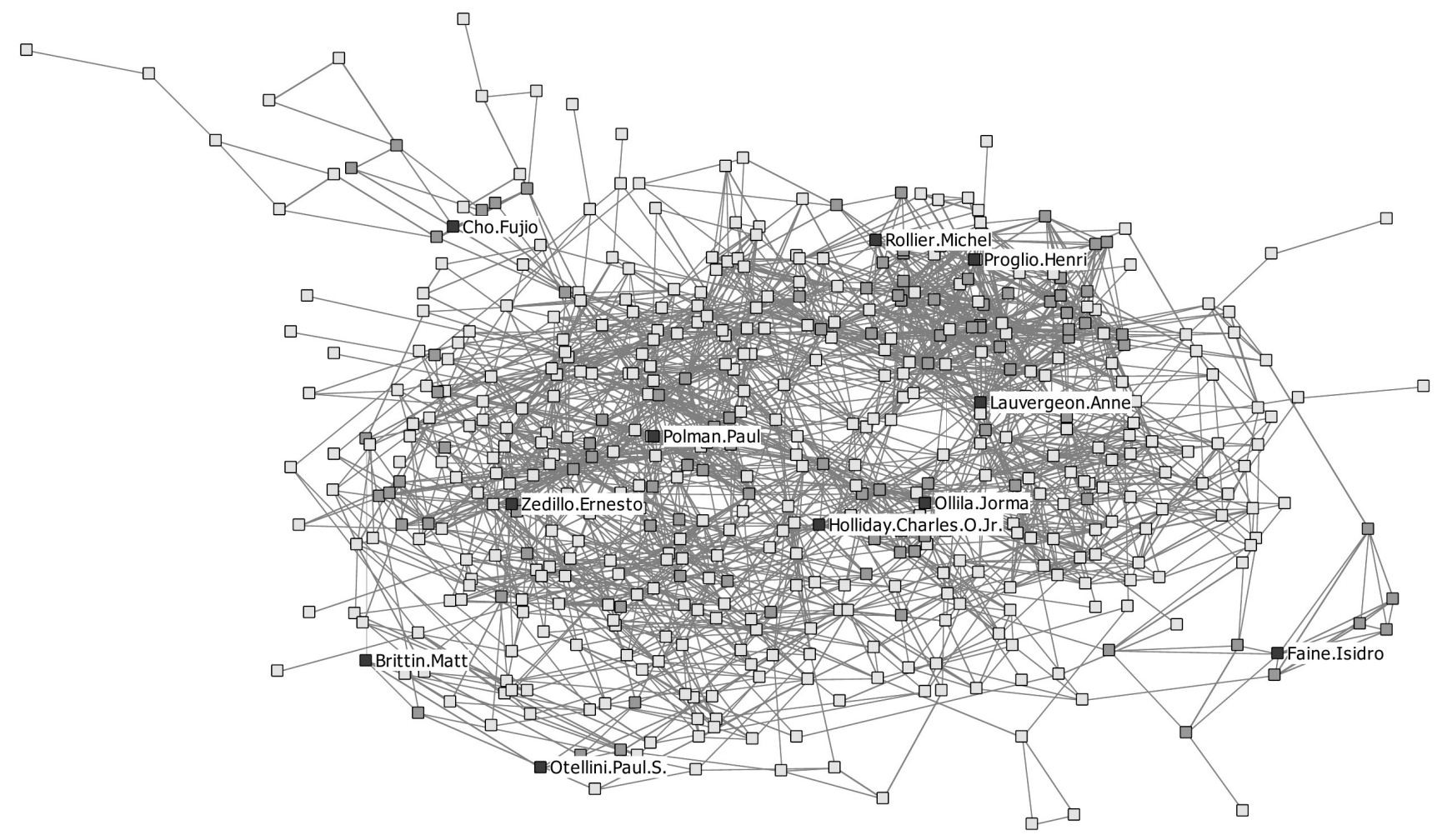

Key

Black: Climate capitalist inner circle members Dark gray: G500 interlockers directly linked to inner circle members Light gray: Other G500 interlockers

Figure 3. Climate capitalist inner circle members among G500 interlockers 